\title{
Historical road system and farmhouses in Apulia
}

\author{
L.P. Caliandro, ${ }^{1}$ R.V. Loisi, ${ }^{2}$ P. Dal Sasso² \\ 1 Department of Agricultural Sciences, food and environment, University of Foggia, Italy, \\ ${ }^{2}$ Department of Agro-Environmental and Territorial Science (Di.S.A.A.T.), Agriculture Faculty, \\ University of Bari, Italy
}

\begin{abstract}
Human settlements often originate from the presence of such natural sustaining water bodies as springs, rivers, or rather from the proximity of relevant infrastructure (roads, harbours, etc.). Rural residential buildings, however, are generally closely linked to the cultivated fields of a farm. A significant example of rural buildings, that particularly identifies some national or regional areas, is that of the Apulian farmhouses known as "masserie", which are considered as an important cultural heritage in the rural territories of that region. These buildings, featuring relevant architectural and landscape characteristics, encompass several functions within them and often host more than one family living there permanently. Territorial distribution of rural buildings and farmhouses in Apulia is diversified and, in general and as already stated, it can depend on the close relationship between the building and its adjacent agricultural lot. Moreover, in the case of the Apulian farmhouses, owing to their specific role in overseeing the territory and asserting land tenure rights, this distribution may have "genetic" origins influenced by other elements, too. The efforts of the present work regarding this issue are to investigate the existing relationships between the Apulian farmhouses system and the "historical" roads already existing when they were built (XII-XIX centuries). Particularly, the study proved if there are any correlations among the Roman roads, the sheep's paths (tratturi) crossing the Apulia region and the farmhouses, both from the point of view of the distance from the roads and the importance of the individual farmhouses. Using GIS software and overlay mapping procedures it was possible to quantify the amount of farmhouses and their concentration within the catchment areas of the aforementioned historical roads, while through his-
\end{abstract}

Correspondence: Lucia Patrizia Caliandro, Department of Agricultural Sciences, food and environment, University of Foggia, Via Napoli, n. 25, 71100 Foggia, Italy.

Mobile: +39.320 .4394648 - Fax: +39.080 .5442962 .

E-mail: lucia.caliandro@unifg.it; l.caliandro@unifg.it

Key words: Historical road system, Farmhouses, Integrated recovery, GIS.

The work is due in equal parts to the authors.

(C) Copyright L.P. Caliandro et al., 2013

Licensee PAGEPress, Italy

Journal of Agricultural Engineering 2013; XLIV(s2):e89

doi:10.4081/jae.2013.s2.e89

This article is distributed under the terms of the Creative Commons Attribution Noncommercial License (by-nc 3.0) which permits any noncommercial use, distribution, and reproduction in any medium, provided the original author(s) and source are credited. torical and territorial in-depth analysis those elements characterizing the most interesting farmhouses from the historical and architectural point of view were identified. The research provided interesting information on the existing relations between historical roads and farmhouses, leading to further considerations on the possibility to enhance some of these monuments, located in rural areas, through the promotion of the "integrated" asset represented by the historical road system, with particular reference to the sheep's paths (tratturi).

\section{Introduction and objectives}

The growing demand for rural and cultural tourism contributed to the revaluation of both the representative role of cities and the "open" territories emphasizing the integrated promotion of the excellences.

In this context, a number of studies were carried out aimed at recognizing elements of historical and cultural importance and identifying structural invariants to be interpreted as strength and starting points in the enhancement of the territory.

The knowledge of the endogenous resources of a territory provides information for its preservation and leads to the individualization of promoting actions consistent with other socio-economic aspects belonging to the territory, in the perspective of its environmentally sustainable development.

A similar virtuous project of wide areas enhancement is connected to the possibility of restoring existing linear elements, such as the historical road system, which possess interesting features increasing their specific cultural value.

Among the characterizing assets of the historical and cultural heritage in the Apulian rural territory there are the "masserie" (as the farmhouses are known in Italian), the most significant architectural emergencies in the rural constructions. They are considered as symbols of the land-owner middle class and emblem of a strong relationship between shape and function, cultivation and agricultural firm.

Indeed, the historical road network is the conceptual and physical medium by which the landscape, environmental and cultural resources are linked, contributing to add value to the whole territory.

Stated the importance of the two systems, the farmhouses and the historical road system (the sheep's paths - "tratturi" - of the sheep pasture - "mena delle pecore" - and the consular roads), it is necessary to find integrated recovery forms concerning their functional and physical connections, too. The very existence of a historical road can favour the restoration of farmhouses and, similarly, the farmhouses restoration can ensure the enhancement of the historical routes. In this way, saving one of the two assets categories will have positive effects on the other.

In the light of such considerations, the aim of the present study is to identify the connections and the interrelations between the farmhouse buildings and the historical road system, i.e. the territorial links existing between the most relevant architectural emergencies of the 
peasant culture and the most important historical infrastructure of the territory, in order to distinguish in quality and quantity those manufacts to be more easily restored and reused due both for their closeness to the above mentioned roads and for their intrinsic value. The study has been carried out on the whole territory of the province of Taranto, after a preliminary analysis of the regional context.

\section{Materials and methods}

\section{Materials}

Apulia region is characterized by a relevant presence of farmhouses, scattered in the whole territory. These farmhouses embody the architectural symbol of the peasant culture and the greatest expression of the rural building, typical of the medieval age till the end of the XIX century (Figure 1).

Surrounded as they were by huge cultivated lands, farmhouses represented the centre of production and organization of the rural work (Calderazzi, 1989). They often offered valuable architectural features, integrated in rural landscape of great suggestion and identification (Figure 2).

Since each farmhouse has its own features due to the social, economic and agricultural reality of the territory to which it belongs, there are no recurrent building techniques but only improvements or differences between one another which stress their identity. This aspect represents the real value of the farmhouses as being tout court cultural assets, not only limited to the peasant world (Dal Sasso et al., 2009)

According to a study carried out by the Department of AgroEnvironmental and Territorial Science of the University of Bari, about 8000 farmhouses were surveyed in the Apulia region, as reported in the 1:25 000 scale official cartography of the Military Geographic Institute (IGM), produced in 1950 (Table 1 - Dal Sasso et al., 2009).

Some of these present relevant historical-architectural features identified in the Cultural Heritage Chart recently produced by the Apulian Regional Administration for the creation of the new Regional
Landscape Plan (Piano Paesaggistico Territoriale Regionale or PPTR Figure 3 -)

The historical routes crossing the regional territory that have been taken into consideration in this study are the Roman consular roads and the "tratturi" (as the sheep's paths are known in Italian).

Until the IV century before Christ, in Southern Italy all the cultural and commercial relationships developed through the pre- or proto-historic road network. It was with the advent of the Romans, between the end of the IV and the beginning of the III century before Christ, that an organized road plan was conceived by the central government.

Despite the almost complete disappearance of the consular roads, they still represent a notable functional and structural example.

Roman roads were born for military reasons. Indeed, the Appia road was built in stages, as the Roman conquest of new territories expanded. Moreover, from the IV to the II centuries before Christ, the "Appula" (Apulian) road system represented the main path for the commercial exchanges with Greece and the East Mediterranean.

Among the 29 Roman roads spreading from Rome to the rest of Italy, the Appia road and the Trajan road are those crossing the Apulian territory (Figure 4).

The first road, built in 330 before Christ by the Consul Appio Claudio, stretched from Rome to Benevento and Taranto, and, later, under the Emperor Traiano, it reached Brindisi.

The Trajan road, also known as "Appia-Traiana or Minuccio Traiana", linked Benevento to Brindisi, passing from Troia, Ordona and Canosa, while on the way between Bitonto and Egnazia, it was made of two stretches, the coastal Trajan road, the "Traiana Costiera" and the Internal Trajan road, the "Traiana Interna". In the Apulian Territory, the Trajan road extends for about 505 kilometres, while the Appia Road is about 194 kilometres long.

Today little is remained of this road system because its long use destroyed many of its archeological traces and also because those paths, which were included in the major routes of the Imperial Age and often used till nowadays, have been rearranged or restored in the course of the centuries (Cippone, 1993).

In this study the historical cartography has been adopted (Otranto, 2007) which reproduces the original map of Giovanni Antonio Rizzi

Table 1. Named farmhouses surveyed by IGM cartography (scale 1:25 000) and by the Apulian Cultural Heritage Chart.

$\begin{array}{lccccccc}\text { Province } & \text { Foggia } & \text { Bat } & \text { Bari } & \text { Brindisi } & \text { Taranto } & \text { Lecce } & \text { Total } \\ \begin{array}{l}\text { Farmhouses surveyed by IGM } \\ \text { cartography }\end{array} & 2587 & 507 & 1820 & 980 & 1157 & 1419 & 8470 \\ \text { Farmhouses surveyed by } & 1144 & 211 & 321 & 539 & 606 & 127 & 2947\end{array}$

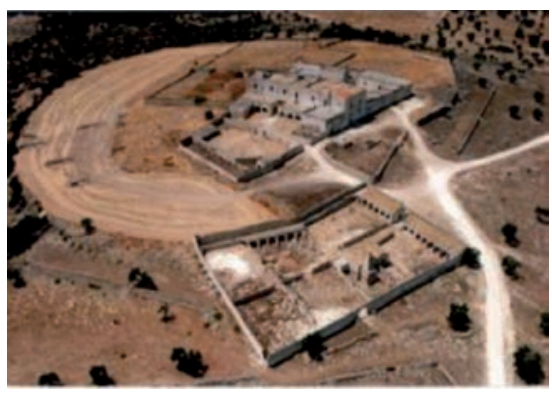

Figure 1. Apulian farmhouse.

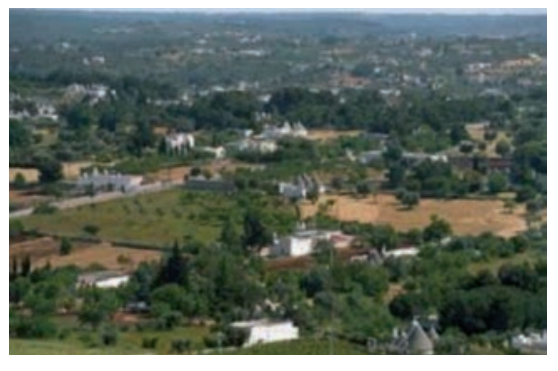

Figure 2. Farmhouses integrated in rural landscapes.

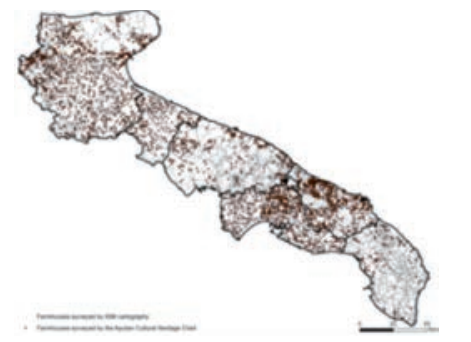

Figure 3. Farmhouses surveyed by IGM cartography (scale 1:25 000) and by the Apulian Cultural Heritage Chart. 
Zannoni drawn for the reign of Naples and dating back to the last twenty years of the XVIII century.

The sheep's paths (Figure 5), deserted or substituted by the ordinary road system in some stretches, nowadays still constitute essential elements of the territorial organization and undoubtedly a symbol of the agro-pastoral civilization (AA.VV., 1999)

In the protohistoric period, the sheep's paths already represented long "grassy roads" where herds and sheep grazed, allowing the transfer out of the coastal lands to the internal ones. Transhumance required a long journey and so it should ensure food (green roads) and resting places (stations, jazzi, hunting lodges, etc.) for the cattle.

For a long time the sheep's paths have been linking roads between the Abruzzo and Molise Appennine pasture and the Apulian plains, representing the core of a fundamental commercial activity for all the different populations developed in Southern Italy, from the Sanniti to the Kingdom of the two Sicilies.

At the beginning of summertime the herd was shepherded towards the mountains. In autumn it was brought back to the plains where it spent winter, through grassy roads called "calles publicae" which could be passed under payment of a duty to the State.

Later on, as deduced by Emperors Teodosio and Giustiniano Codes it's known that these roads were called "tractoria", from which derived the term "tratturi" that is still in use.

The origin of transhumance is very ancient and widespread in a lot of regions, both Italian and foreigner, where, under different names, it is possible to distinguish these pasture communicating roads.

The sheep's paths usually took their name from the arrival lands or a nearer centre.

Their economic role is already present in the Roman times. Their use was subdued to the payment of a tax, the "publicum vectigal", which varied according to the number and the weight of the animals.

In the Middle Ages Alfonso I d'Aragona established the "Regia dogana per la mena delle pecore in Puglia", the institution which administered the sheep's paths system and was in charge of collecting the Royal tax by the herds owners who used the State property lands for the cattlerearing.

The Regia Dogana had its first venue in Lucera and later in Foggia, where it was present from 1447 to 1806 .

The golden age of the sheep's paths lasted till 1806, when Giuseppe Bonaparte abolished the Regia Dogana. Since then the transhumance roads decayed and any law effort of protection and restoration failed (Colapietra, 1985)

The main sheep's paths were linked by a series of branches and little sheep's paths; the width of the first was fixed in 60 steps or Neapolitan steps, corresponding to 111,11 metres; the second has a 30 steps $(55,55$ metres) width and the third, which linked the sheep's paths and gave access to the mountain pastures and locations, has a width that varied from 20,15 steps (37,31 metres) to 10 steps (18,52 metres).

According to a list compiled in 1912, the entire extension of the sheep's paths system amounted to 2978.29 kilometres for a total of 21 000 hectares and included five regions: Abruzzo, Molise, Apulia, Campania and Basilicata.

As far as the Apulian territory is concerned, the sheep's paths system extends for about 1990 kilometres (Figure 6) and crosses the territories of the province of Foggia, where the sheep's paths network is very dense, and the province of Bari, mainly in the pre-Murgia and Murgia area, to become thicken again in the province of Taranto.

In this study the sheep's paths map was adopted, as reported by the Apulian Territorial Urban Planning/Landscape Map (Piano Urbanistico Territoriale Tematico/Paesaggio or PUTT/P). Apulian Regional Administration is working on the identification of restored, not yet restored and/or deserted stretches, through a photographic interpretation of the regional ortho-photography (Figure 7).

As this study area the province of Taranto was chosen, due to the fact that it is largely affected by the presence of farmhouses recognized as cultural heritage and, more specifically, for the massive concentration of valuable farmhouses (reported in the Cultural Heritage Chart) in the central area of the province, including the municipalities of Martina Franca, Grottaglie and Taranto, crossed by a thick net of sheep's paths and by the historical Appia road.

Moreover, new forms of rural tourism have been developing in this area. Those are recently aimed at the quality of products and services, and tend to promote the cultural, landscape and environmental peculiarities which give an effective contribution to the identification and enhancement of the heritage linked to the historical road system.

\section{Methodology}

The research work is composed by four phases. In the first, data concerning farmhouses located in the territory of Taranto have been analyzed, with a particular reference to those buildings having a significant historical and architectural value. To this aim, the data gathered by the project of the Apulian farmhouses classification, already started by the Department of Agro-Environmental and Territorial Science of the University of Bari, have been used.

The final result of cited work has been the synthesis of the specific features of the analyzed farmhouses (location, territorial layout, surface, volume, typological, structural, functional and architectural characteristics, historical information, present destination, maintenance status, firm peculiarities).

Moreover, using a GIS tool (Arcview 9.3.2 software package), it was created the identification map of the valuable farmhouses, as detected from the ones reported in the 1:25 000 scale cartography of the Military Geographic Institute (IGM). Those map was then overlapped to the

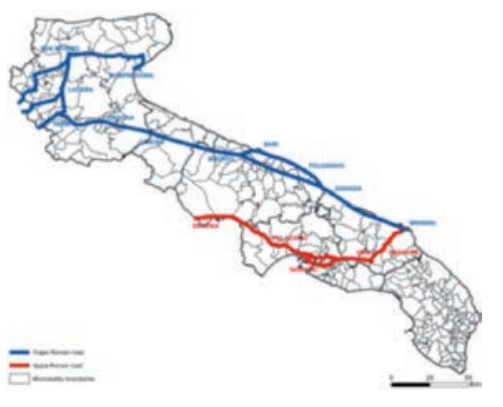

Figure 4. Roman consular roads.

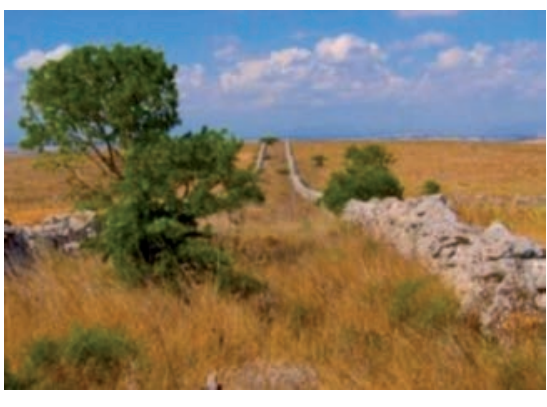

Figure 5. Part of a neglected sheep's path.

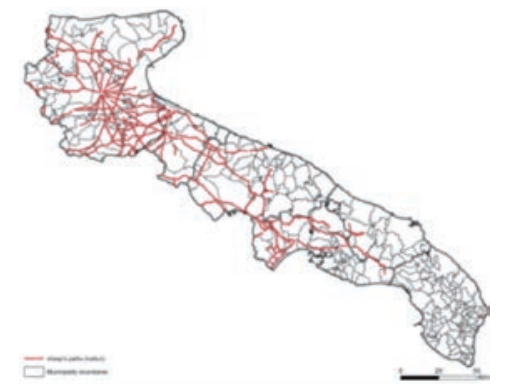

Figure 6. Sheep's paths system in Apulia. 
Apulian Cultural Heritage Chart, which in turn reports further valuable farmhouses.

The second phase consisted in the analysis of the main historical paths of the Apulian territory, the georeferencing of the historical cartography concerning the consular roads and the sheep's paths system (Otranto, 2007), and the identification of those stretches which mark the territory of Taranto.

In the third phase the correlation between the farmhouses system and the historical path network in the province of Taranto has been evaluated, according to the following principle.

With the help of a GIS tool, the catchment area (a buffer having a distance of $1 \mathrm{~km}$ ) of the historical paths crossing the analyzed territory (the Appia Roman road and the sheep's paths) has "built". Subsequently those farmhouses falling within the aforementioned areas, and related to each path, have been detected (Figures 8 and 9).

This last phase led to the quantitative evaluation of the farmhouses set in the catchment area of the historical road system.

\section{Results and discussion}

This study allowed the evaluation of the existing correlation between the farmhouses and the main historical paths in the province of Taranto.

It was noticed that a section of the Appia road, about the $48 \%$ of its total length, was used as sheep's paths.

The analysis of the catchment area (buffer), derived as previously described, both for the Appia road and the sheep's paths, highlighted the fact that the farmhouses located inside those areas are the $31 \%$ of the total amount of farmhouses located within the boundaries of the province of Taranto. On the other side, a considerable number of farmhouses, about the $69 \%$ of the total, is scattered outside the catchment area of the various historical paths examined.

Besides, the importance of the farmhouses inside those areas is great, if we particularly consider the fact that they were real landmarks for the internal territories and, for this reason, they were generally built far from the main communication roads and the urban centres.

Being a principal historical road, the Appia road path joins the main functional and structural poles of the territory, as the urban centres, and has a highly value also for its correlation to the farmhouses. This correlation in similar to the one existing between the farmhouses and the sheep's paths, as shown in Table 2, where 1.04 farms $/ \mathrm{km}$ for the Appia road and 1.02 farms $/ \mathrm{km}$ for the sheep's paths have been detected.

This is clearly justifiable because, in different periods of time, this road was used as a sheep's paths in the stretch between the Tratturo Melfi - Castellaneta (sheep's paths Melfi-Castellaneta) and the Tratturello Tarantino (Taranto little sheep's paths), for a total length of about 53 kilometres. Considering this common portion (Figure 10), indeed, it can be noticed that, due to the presence of 69 farmhouses in the catchment area, their impact value grows to 1.30 in relation to the length of the path.

The percentage distribution (Table 2) of the farmhouses placed within the catchment area of the sheep's paths (27\% out of 1157 provincial farmhouses) still represents a considerable amount, particularly considering the great extension of the sheep's paths system of the province.

This allow to highlight the functional connection between the sheep's paths and the farmhouses, i.e. between the transhumance sheep-breeding and the resident breeding. Moreover, the considerable linear length of the different paths here analyzed, represents a structural and functional axis of the extra urban territory which seems to be

Table 2. Farmhouses placed within the catchment area of the historical paths.

\begin{tabular}{|c|c|c|c|c|}
\hline Historical road system & $\begin{array}{l}\text { Farmhouses } \\
\text { (N) }\end{array}$ & $\begin{array}{l}\text { Road length } \\
\qquad(\mathrm{km})\end{array}$ & $\begin{array}{c}\text { Farmhouses/km } \\
\text { (N/km) }\end{array}$ & $\begin{array}{l}\text { Farmhouses detected/ } \\
\text { Provincial farmhouses } \\
\text { (equal to } 1157 \text { ) } \\
(\%)\end{array}$ \\
\hline Appia Roman road & 114 & 109 & 1.04 & 10 \\
\hline Sheep's paths (tratturi) & 314 & 306 & 1.02 & 27 \\
\hline Sheep's paths (tratturi) overlapped with Appia Roman road & 69 & 53 & 1.30 & 6 \\
\hline Total & $359(428-69)$ & $362(415-53)$ & $0,99(359 / 362)$ & 31 \\
\hline
\end{tabular}

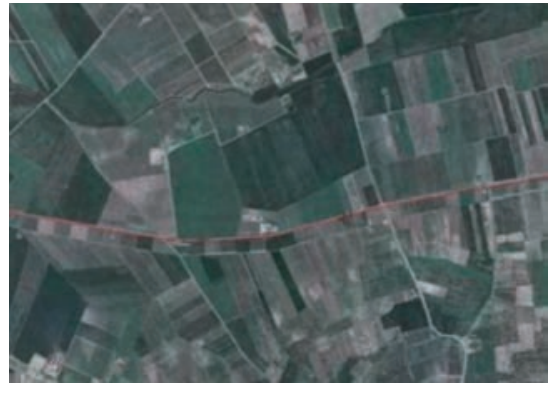

Figure 7. Ortho-photographic identification of a sheep's path stretch.

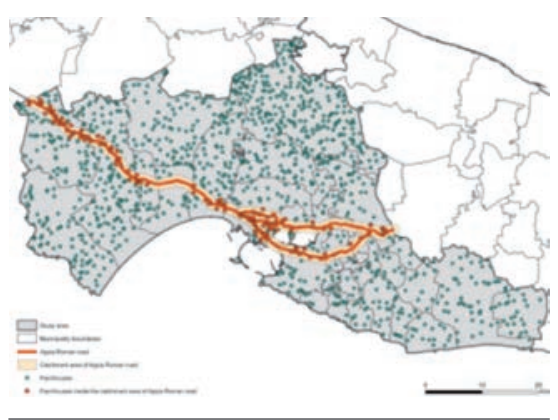

Figure 8. Relationships between the Appia Roman consular road and the farmhouses system.

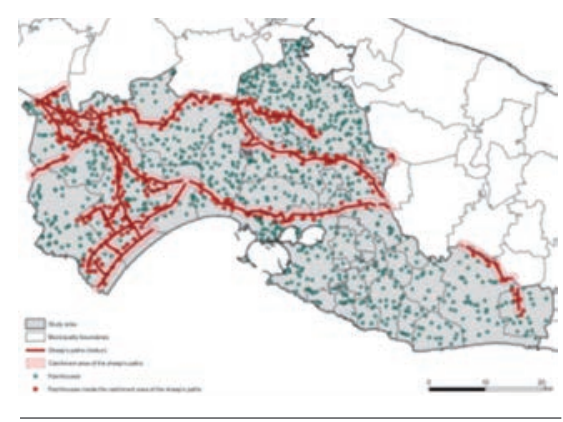

Figure 9. Relationships between the sheep's paths and the farmhouses system. 
particularly interesting from the point of view of an integrated restoration of the rural building heritage.

Given that a stretch of the Appia road ( the $48 \%$ of its length, with the $60 \%$ of farmhouses placed in the path buffer) coincides with the Tratturo Melfi - Castellaneta and the Tratturello Tarantino, to be discussed later, the portion which completes the historical path crosses the city of Taranto and presents an interesting concentration of farmhouses exactly in the outskirts of the city.

Among the valuable farmhouses in that area, there is Mucchio farmhouse (Figure 11), articulated around a yard and composed by different structures that started from the original core built to serve the different agricultural, residential and defensive functions. The chapel represents a unique element, since it is completely isolated from the working area of the farm (Mongiello, 1984). Nowadays Mucchio farmhouse lay abandoned in the industrial area of the Italsider of Taranto.

The sheep's paths counting a massive presence of farmhouses in their catchment area are the Tratturo Melfi-Castellaneta, the Tratturello Orsanese and the Tratturello Gorgo-Parco (Table 3). The farmhouses placed in the catchment areas related to the sheep's paths located in the north-west side of Taranto present characteristics that differ to those of the farmhouses placed within the Murgia dei Trulli, where the Tratturello Gorgo-Parco is located.

The first are characterized by largely built areas "due to the extension of the cultivated lands and the distance from the centres of labour recruiting. They looked like small villages, with the peasant houses grouped around the manor house and the church" (Colamonico, 1970).

Among the most valuable farmhouses of this area there is the Tafuri farmhouses, near the municipality of Castellaneta (Figure 12).

The farmhouses placed in the catchment area of the Tratturello Gorgo-Parco are generally characterized by a two-floor building, the manor house, and by rural buildings with the typical shape of "trullo" grouped together, in pair or in line creating an open yard with the manor house (Figure13).

Among the most significant examples of this farmhouses typology

Table 3. Farmhouses placed within the catchment area of the individual sheep's paths.

\begin{tabular}{lccc} 
Sheep's paths & $\begin{array}{c}\text { Farmhouses } \\
(\mathbf{N})\end{array}$ & $\begin{array}{c}\text { Road length } \\
(\mathbf{k m})\end{array}$ & $\begin{array}{c}\text { Farmhouses/km } \\
(\mathbf{N} / \mathbf{k m})\end{array}$ \\
Melfi - Castellaneta & 30 & 14.8 & 2.02 \\
Santeramo in Colle - Laterza & 24 & 16.2 & 1.48 \\
\hline Martinese & 100 & 92.5 & 1.08 \\
Murge & 11 & 6.8 & 1.61 \\
\hline Tarantino & 52 & 57.8 & 0.90 \\
Orsanese & 30 & 16.9 & 1.77 \\
\hline Quero & 14 & 9.8 & 1.42 \\
Palagiano - Bradano & 27 & 28.6 & 0.94 \\
\hline Pineto & 13 & 17.6 & 0.74 \\
Bernalda - Ginosa - Laterza & 13 & 13.5 & 0.97 \\
\hline Pini & 11 & 8,3 & 1,34 \\
Ferre & 5 & 4,3 & 1,16 \\
\hline Gorgo - Parco & 33 & 18,9 & 1,74 \\
Total & 363 & 306 & \\
\hline
\end{tabular}

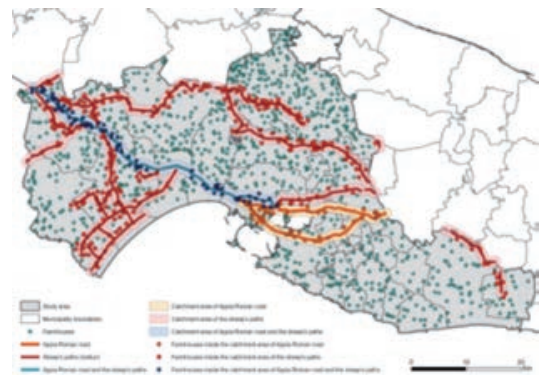

Figure 10. Relationships among the Appia Roman consular road, the sheep's paths and the farmhouses system.

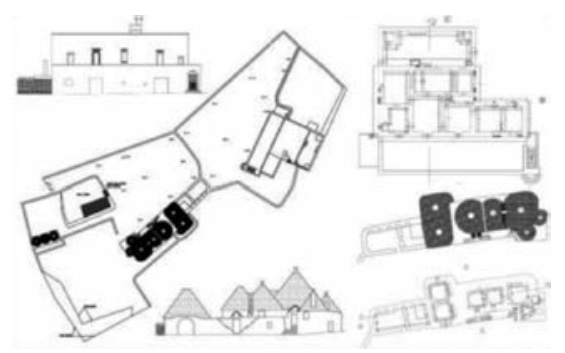

Figure 13. Architectonic survey of a farmhouse with trulli in Martina Franca countryside.

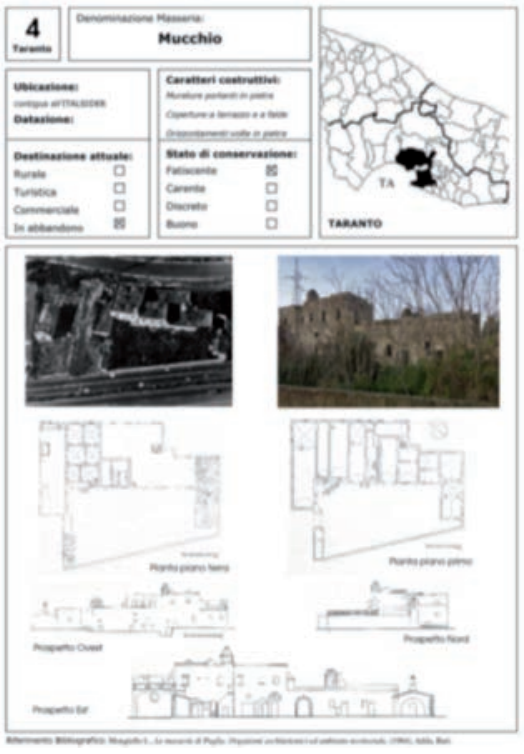

Figure 11. Mucchio farmhouse in Taranto.

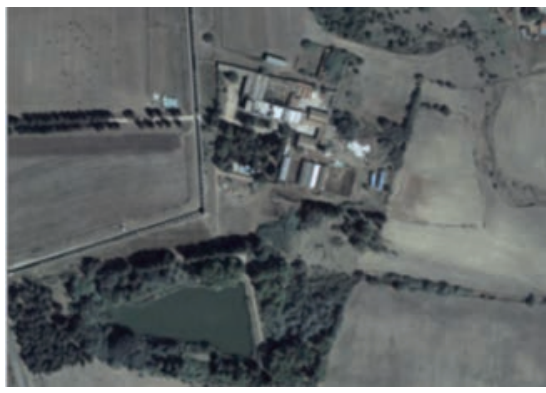

Figure 12. Tafuri farmhouse in Castellaneta countryside.

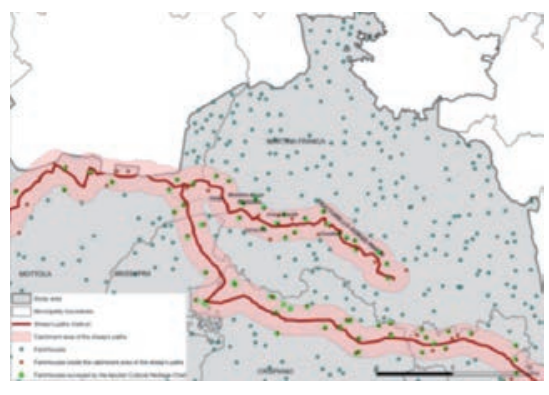

Figure 14. Valuable farmhouses in the catchment area of Tratturello Gorgo-Parco. 
within the catchment area of the Tratturello (Figure 14), there are the farmhouses named Motolese Murge (Figure 15a), Paglierone (Figure 15b), Croce Grande (Figure 16a), Cavaliere (Figure 16b), Gorgo (Figure 17a) and Carrucola (Figure 17b).

Along the Tratturello Martinese, the longest in the province of Taranto, presenting a great number of buildings in its catchment area (100 farmhouses), there are stretches presenting a relevant concentration of farmhouses, particularly near Crispiano-Grottaglie and Castellaneta-Laterza, which include on the same path the two typologies of farmhouses above mentioned.

\section{Conclusions}

Even if limited to the province of Taranto, this research drew a connection between the two systems, the road and the farmhouses ones, as points of reference for similar studies in those areas affected by the same existing structures.

The study results also suggest a method to identify sheep's paths stretches still to be restored by means of a dedicated photo-interpretation. This study allows to create a link between the farmhouses system and the one relating to the main regional paths having historical and cultural origin.

The results clearly showed a complex relationship between the two systems, so that it can be easily made hypothesis about an integrated use of the territory, that comprehends both the agricultural and livestock realities (the farmhouses), and the cultural touristic value (the routes).

This will mean to support the rural territory development with the enhancement of its cultural resources, that can be pursued both through restoration and re-use of the farmhouses, keeping in mind their touristic, didactic, leisure and research use destination, and increasing the value of the sheep's paths, the role of which could be emphasized through information points, signals, etc.
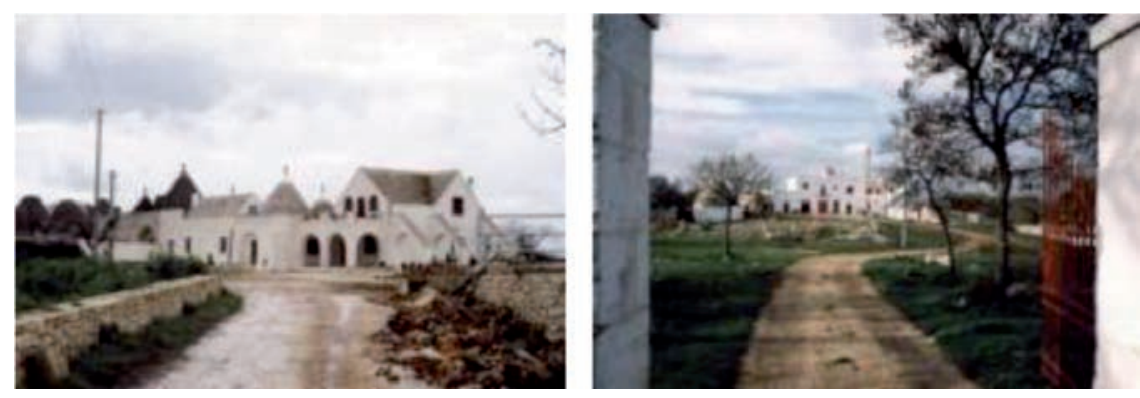

Figure 15a. Motolese Murge farmhouse (on the left) and Figure 15b. Paglierona farmhouse (on the right), both located in Martina Franca countryside.
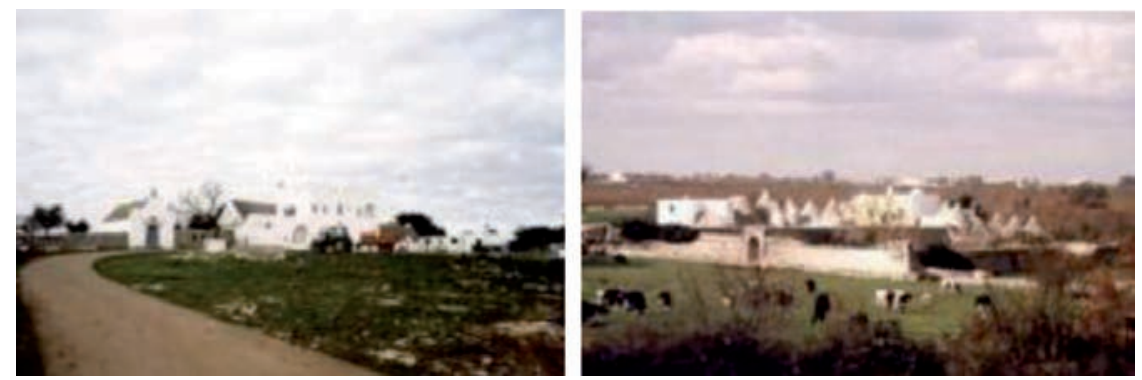

Figure 16a. Croce Grande farmhouse (on the left) and Figure 16b. Cavaliere farmhouse (on the right), both located in Martina Franca countryside.
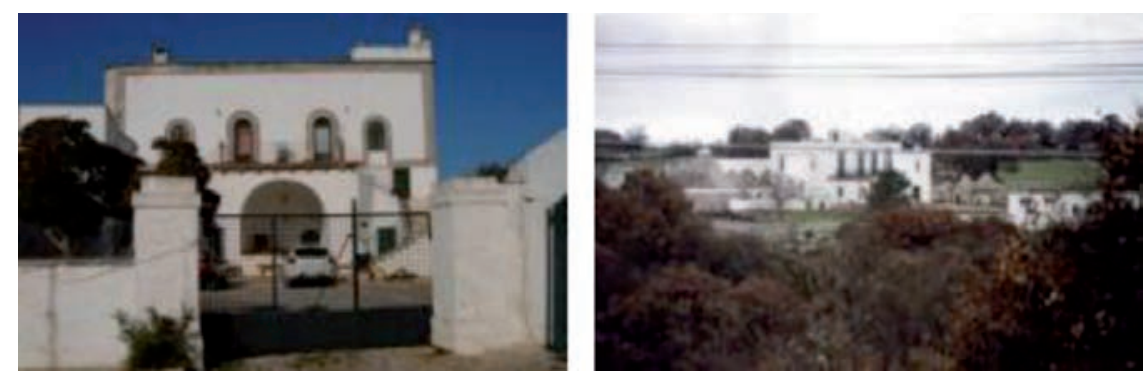

Figure 17a. Gorgo farmhouse (on the left) and Figure 17b. Carrucola farmhouse (on the right), both located in Martina Franca countryside. 
All these hypothesis are particularly advisable since most of the farmhouses in the studied area are only partially abandoned. In fact, they are generally used for agriculture or, in some cases, for touristic accommodation.

This research results can also integrate the previous classification work of the farmhouses, adding to them a further significance as to a territorial parameter of evaluation.

In the perspective of a sustainable development, the investigation of integrated endogenous resources is a key action for a correct use of the territory and for a future development respectful of the environment and the landscape.

In conclusion, this work may provide information for the definition of territorial plans which, far from being only an ideal guide, should also constitute practical guidelines for any possible form of intervention.

\section{References}

AA.VV. 1999. I territori della transumanza: una rete per i parchi. Dierre edizioni, Chieti.

Calderazzi A. 1989. L'architettura rurale in Puglia: le masserie. Schena, Fasano.

Cippone N. 1993. La Via Appia e la terra jonica. Nuova Editrice Apulia, Martina Franca.

Colamonico C. 1970. La casa rurale nella Puglia. Olschki, Firenze.

Colapietra R. 1985. I grandi tratturi nella tematica attuale dei beni ambientali. Proc. 4th Congr. Prehistory - Proto-history - History of Daunia. Civica Amministrazione-Biblioteca Comunale "A. Minuziano"-Archeoclub d'Italia, San Severo.

Dal Sasso P., Ottolino A., Loisi R.V. 2009. Masserie di Puglia: Censimento e Analisi delle tipologie. Estimo e Territorio vol. II: 42-54.

Mongiello L. 1984 Le masserie di Puglia. Organismi architettonici ed ambiente territoriale. Adda, Bari.

Otranto G., 2007 Cento itinerari più uno in Puglia. Gelsorosso, Bari. 